\title{
Total occlusion of the left main coronary artery presenting as ST-elevation myocardial infarction
}

\author{
Chen-Yuan Su, ${ }^{1}$ Ping-Yen Liu, ${ }^{1,2}$ Po-Wei Chen ${ }^{1,2}$
}

'Division of Cardiology, Department of Internal Medicine, National Cheng Kung University Hospital, College of Medicine, National Cheng Kung University, Tainan, Taiwan ${ }^{2}$ Institute of Clinical Medicine, College of Medicine, National Cheng Kung University, Tainan, Taiwan

\section{Correspondence to} Dr Po-Wei Chen, huntershobow@gmail.com

Accepted 9 February 2019
Check for updates

(C) BMJ Publishing Group Limited 2019. No commercial re-use. See rights and permissions. Published by BMJ.

\footnotetext{
To cite: Su C-Y, Liu P-Y, Chen P-W. BMJ Case Rep 2019;12:e228658. doi:10.1136/bcr-2018228658
}

\section{DESCRIPTION}

This 59-year-old woman with diabetes mellitus and hypertension presented to emergent department with resting onset chest pain and diaphoresis. Initial ECG showed sinus tachycardia, right bundle branch block (RBBB) pattern, left anterior fascicular block (LAFB) and diffuse ST-segment depression with lead I and aVL elevation (figure 1). Under the impression of acute myocardial infarction with cardiogenic shock, emergent cardiac catheterisation was arranged and showed left main coronary artery (LMCA) total occlusion (figure 2). Her ECG pattern recovered after timely revascularization (figure 3), but low cardiac output signs with multiple organ hypoperfusion still happened. Intra-aortic balloon pump was placed for mechanical support, and inotropic agent was administrated. Her general condition improved gradually after mechanical support, and she was discharged uneventfully 7 days after the event (figure 4).

Conduction disturbance may be presented in anterior myocardial infarction due to defected blood supply from septal branch. RBBB (usually with $\mathrm{LAFB}$ ) is one of the frequent presentations of

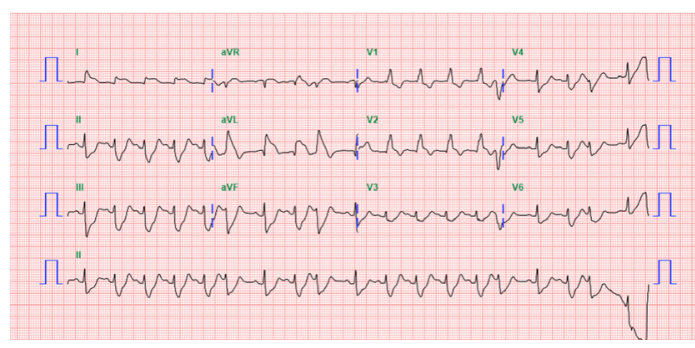

Figure 1 Right bundle branch block (RBBB)+ left anterior fascicular block (LAFB) pattern, and diffuse STsegment depression with lead I and aVL elevation.

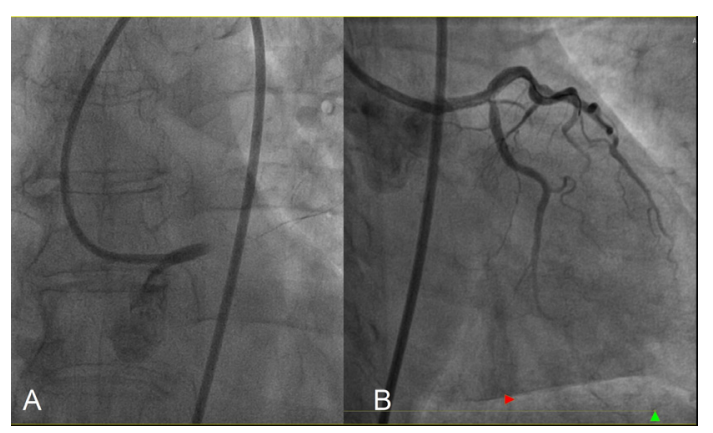

Figure 2 (A) Initial coronary angiography showed left main coronary artery (LMCA) occlusion. (B) Final image after stent deployment at LMCA to left anterior descending artery.

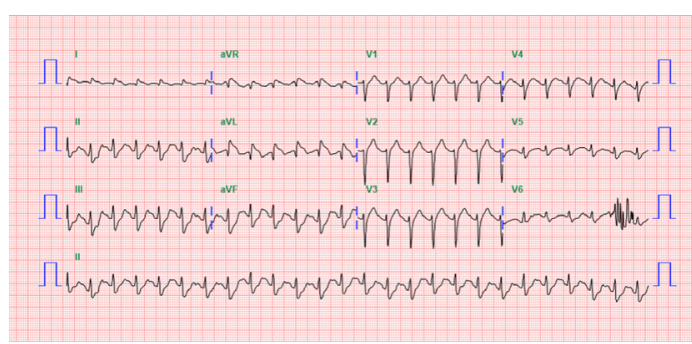

Figure 3 ECG after percutaneous coronary intervention.

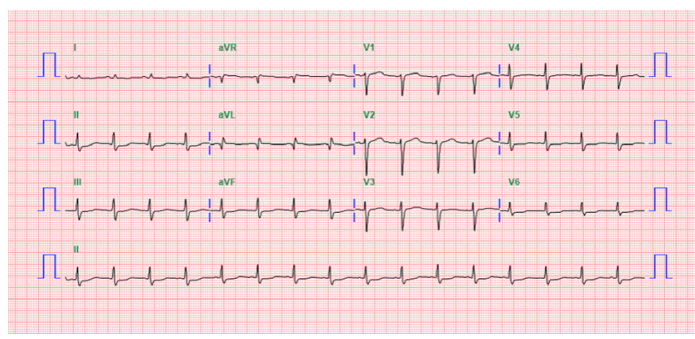

Figure 4 ECG 7 days later after percutaneous coronary intervention.

LMCA occlusion which may be overlooked sometimes and misinterpreted as RBBB when considering the ST segment as part of QRS complex. Acute myocardial infarction with $\mathrm{RBBB}$ has high mortality and poor prognosis. ${ }^{1}$

Among different types of ECG patterns of LMCA occlusion, aVR elevation with diffuse ST depression was the one frequently described which reflects circumferential subendocardial ischaemia. The aVR elevation may be explained by ischaemia of the basal interventricular septum pointing in a superior direction towards lead aVR (and aVL). ${ }^{2}$

However, in our case, the most obvious ST elevation was at lead I and avL. ST elevation in leads I and aVL usually indicated ischaemia at anterolateral territory, with the occlusion of left anterior descending artery proximal to the first diagonal branch, and which is less reported as LMCA occlusion. In our case, the site of occlusion was at LMCA which could be explained by right-side-dominant coronary arteries with small territory of left circumflex artery. Previous study showed that ST elevation in both leads I and aVL is an indicator of extensive ischaemia and may lead to poor prognosis. ${ }^{23}$

In summary, the ECG of our case indicates LMCA occlusion with extensive ischaemia, and prompt diagnosis with revascularisation has been mandatory. The duration of occlusion is highly related to the amount of myocardial salvage and future left ventricular dysfunction. Cardiogenic shock 


\section{Learning points}

- ST elevation may be masked in right bundle branch block with or without LAFB, and identification of QRS complex and ST segment is crucial in accurate diagnosis.

- ST elevation in the precordial leads as well as in leads I and aVL usually indicates ischaemia at anterolateral territory and tends to be pathologically extensive. Left main coronary artery occlusion should be considered.

- Acute heart failure still may present despite timely revascularisation. Mechanical support should be applied for preventing further multiple organ failure.

frequently presents in patients with LMCA occlusion, and timely mechanical supports should be considered as important as emergent revascularisation in such cases.
Contributors Su CY was the physician of the patient, and also participated in patientcare. Su CY drafted the manuscript. Chen PW and Liu PY supervised the findingsof this work and designed the figures. All authors discussed the results andcontributed to the final manuscript.

Funding The authors have not declared a specific grant for this research from any funding agency in the public, commercial or not-for-profit sectors.

Competing interests None declared.

Patient consent for publication Not required.

Provenance and peer review Not commissioned; externally peer reviewed.

\section{REFERENCES}

1 Xiang L, Zhong A, You T, et al. Prognostic significance of right bundle branch block for patients with acute myocardial infarction: a systematic review and meta-analysis. Med Sci Monit 2016;22:998-1004.

2 Nikus KC, Eskola MJ. Electrocardiogram patterns in acute left main coronary artery occlusion. J Electrocardiol 2008;41:626-9.

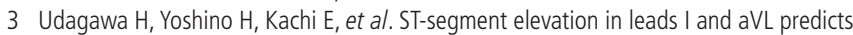
short-term prognosis in acute anterior wall myocardial infarction. Am J Cardiol 2000;85:101-4.

Copyright 2019 BMJ Publishing Group. All rights reserved. For permission to reuse any of this content visit https://www.bmj.com/company/products-services/rights-and-licensing/permissions/

BMJ Case Report Fellows may re-use this article for personal use and teaching without any further permission.

Become a Fellow of BMJ Case Reports today and you can:

- Submit as many cases as you like

- Enjoy fast sympathetic peer review and rapid publication of accepted articles

- Access all the published articles

- Re-use any of the published material for personal use and teaching without further permission

For information on Institutional Fellowships contact consortiasales@bmjgroup.com

Visit casereports.bmj.com for more articles like this and to become a Fellow 